\title{
An investigation of the role of brand image on consumer loyalty
}

\author{
Fatemeh Izadi Manesh and Somayeh Hozouri*
}

Department of Management, Islamic Azad University, South Tehran Branch, Tehran, Iran

\begin{tabular}{l}
\hline C H R O N I C L E \\
\hline Article history: \\
Received May 12, 2013 \\
Received in revised format \\
12 August 2013 \\
Accepted 28 September 2013 \\
Available online \\
October 6 2013 \\
\hline Keywords: \\
Customer loyalty \\
Brand image \\
Marketing planning
\end{tabular}

Marketing planning

\section{A B S T R A C T}

\begin{abstract}
This paper presents an investigation on the role of brand image on customer loyalty on rubber industry. The proposed study designs a questionnaire in Likert scale consists of 27 questions, distributes it among some Iranian experts in rubber industry and analyzes it based on principal component analysis. During the survey, the number questions are reduced to 23. Cronbach alpha is calculated as 0.812 and Kaiser-MeyerOlkin Measure of Sampling Adequacy and Approx. Chi-Square are 0.671 and 2375, respectively. Based on the results of our survey, we have derived six factors including penetration strategy, infrastructure characteristics, competitive pricing, target marketing strategy, communication strategy and market characteristics.
\end{abstract}

\section{Introduction}

Brand is one of the most important factors for building trust among customers and rubber industry is one of them (Franco, 1990; Aaker, 2010; Leuthesser et al., 2011; Hsieh \& Li, 2011). During the past few years, there has been a high competition in rubber industry, which has reduced profit margin in this industry and only efficient and well known rubber producers could survive (Stigler, 1961; Stiglitz \& Weiss 1981). Therefore, there is a necessity to investigate brand characteristics and detect how to form a good brand in such competitive market and there are literally many studies associated with how to build brand. Erdem and Swait $(1998,2004)$, for instance, studied the impact of brand credibility, trustworthiness and expertise, on brand choice and consideration across multiple product categories. They reported that brand credibility could increase probability of inclusion of a brand in the consideration set. Brands may affect various stages of consumer choice processes, and hence, various components of consumer utility functions. Previous conceptual and empirical work focused on the effects of brands on consumer perceptions of tangible and intangible product attributes. Erdem

\footnotetext{
*Corresponding author

E-mail address: saho84@rocketmail.com (S. Hozouri) 
et al. (2002) extended the work on brand effects with information economics to find out whether consumer price sensitivity could influence overall attractiveness or utility. They investigated how the impact of product price on consumer utility was moderated by brand credibility. To explore the impact of brand credibility on consumer price sensitivity across categories that could involve different levels of consumer uncertainty, they applied the analysis for four products including frozen concentrate juice, jeans, shampoo and personal computers. These categories varied in the degree of potential consumer uncertainty about product attributes, as well as in a number of other categoryspecific features, which could impact consumer sensitivity to uncertainty. They reported that brand credibility could decrease price sensitivity and although the direction of the effect was the same, the magnitude of brand credibility's impact on consumer choices and price sensitivity could be different across product categories, as a function of product category characteristics, which impact potential consumer uncertainty and consumer sensitivity to such uncertainty.

Sweeney and Swait (2008) studied the important additional impact of the brand in managing the churn of current customers of relational services. They tried to find out whether the credibility of the brand could underlay the effect that the brand could play in this process. In their survey, brand maintained a substantial role on managing long-term customer relationships, and reported how the usual tools of customer relationship management, satisfaction and service quality influenced brand credibility. Berry (2000) presented a service-branding model and stated that branding was not just for tangible goods and it could be considered as a principal success driver for service organizations as well. Gilliland and Bello (2002) studied two sides to attitudinal commitment including the impact of calculative and loyalty commitment on enforcement mechanisms in distribution channels. Wray et al. (1994) presented a neural network with two outcome components of relationship quality, relationship satisfaction and trust, and five input antecedents including the salesperson's sales orientation, customer orientation, expertise, ethics and the relationship's duration. Harris and Goode (2004) studied online service dynamics on four levels of loyalty and the pivotal role of trust.

\section{The proposed study}

This paper presents an investigation on the role of brand image on customer loyalty on rubber industry. The proposed study designs a questionnaire in Likert scale consists of 27 questions, distributes it among some Iranian experts in rubber industry and analyzes it based on principal component analysis. Cronbach alpha is calculated as 0.812. In addition, Kaiser-Meyer-Olkin Measure of Sampling Adequacy and Approx. Chi-Square are 0.671 and 2375, respectively. Since the proposed study of this paper uses principal component analysis and the method is sensitive to skewness of the data we have carefully monitored the data and removed four questions leaving it to have 23 questions. Table 1 summarizes the results of our survey on communalities. Fig. 1 demonstrates the results of Scree plot.

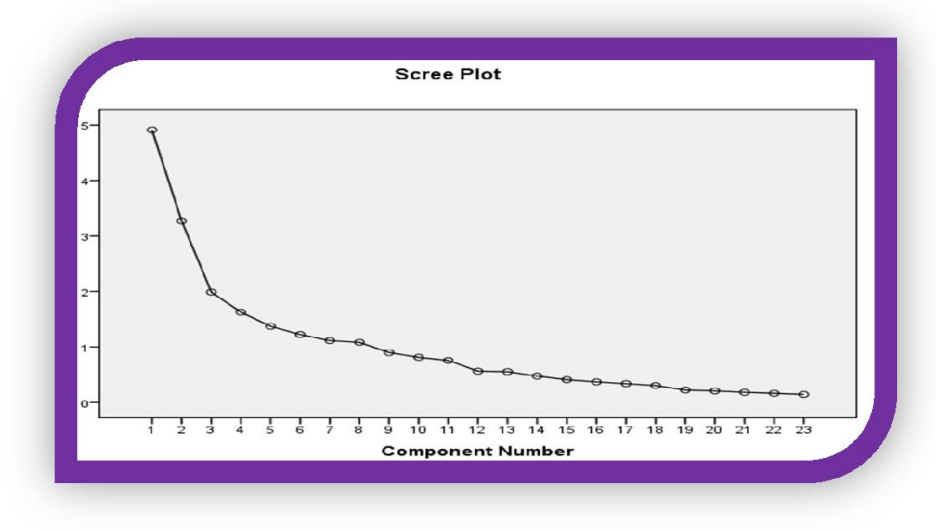

Fig. 1. The summary of Scree plot 
As we can observe from the results of Fig. 1, there are six factors, which could be extracted for further studies. In addition, as we can observe from the results of communalities given in Table 1, most factors are well above the minimum acceptable level of 0.5 . Table 2 demonstrates the results of factor analysis on these factors.

\section{Table 1}

The summary of communalities

\begin{tabular}{|ccc}
\hline & Communalities & Extraction \\
\hline VAR00005 & Initial & .776 \\
\hline VAR00006 & 1.000 & .800 \\
\hline VAR00010 & 1.000 & .713 \\
\hline VAR00012 & 1.000 & .708 \\
\hline VAR00013 & 1.000 & .620 \\
\hline VAR00014 & 1.000 & .659 \\
\hline VAR00015 & 1.000 & .779 \\
\hline VAR00016 & 1.000 & .685 \\
\hline VAR00017 & 1.000 & .680 \\
\hline VAR00019 & 1.000 & .699 \\
\hline VAR00020 & 1.000 & .728 \\
\hline VAR00021 & 1.000 & .813 \\
\hline VAR00022 & 1.000 & .713 \\
\hline VAR00024 & 1.000 & .840 \\
\hline VAR00025 & 1.000 & .780 \\
\hline VAR00026 & 1.000 & .691 \\
\hline VAR00007 & 1.000 & .788 \\
\hline VAR00018 & 1.000 & .821 \\
\hline VAR00027 & 1.000 & .697 \\
\hline VAR00001 & 1.000 & .793 \\
\hline VAR00003 & 1.000 & .706 \\
\hline VAR00004 & 1.000 & .638 \\
\hline
\end{tabular}

Table 2

The summary of principal component analysis after rotation

\begin{tabular}{|c|c|c|c|c|c|c|c|c|c|}
\hline \multirow[t]{2}{*}{ Component } & \multicolumn{3}{|c|}{ Initial Eigenvalues } & \multicolumn{3}{|c|}{ Extraction Sums of Squared Loadings } & \multicolumn{3}{|c|}{$\begin{array}{c}\text { Total Variance Explained } \\
\text { Rotation Sums of Squared } \\
\text { Loadings }\end{array}$} \\
\hline & Total & $\begin{array}{c}\% \text { of } \\
\text { Variance }\end{array}$ & $\begin{array}{c}\text { Cumulative } \\
\%\end{array}$ & Total & $\begin{array}{c}\% \text { of } \\
\text { Variance }\end{array}$ & $\begin{array}{c}\text { Cumulative } \\
\%\end{array}$ & Total & $\begin{array}{c}\% \text { of } \\
\text { Variance }\end{array}$ & $\begin{array}{c}\text { Cumulative } \\
\%\end{array}$ \\
\hline 1 & 4.915 & 21.368 & 21.368 & 4.915 & 21.368 & 21.368 & 2.913 & 12.665 & 12.665 \\
\hline 2 & 3.273 & 14.229 & 35.598 & 3.273 & 14.229 & 35.598 & 2.536 & 11.027 & 23.692 \\
\hline 3 & 1.989 & 8.648 & 44.245 & 1.989 & 8.648 & 44.245 & 2.451 & 10.656 & 34.348 \\
\hline 4 & 1.628 & 7.077 & 51.322 & 1.628 & 7.077 & 51.322 & 2.219 & 9.649 & 43.997 \\
\hline 5 & 1.373 & 5.969 & 57.291 & 1.373 & 5.969 & 57.291 & 2.120 & 9.218 & 53.214 \\
\hline 6 & 1.224 & 5.322 & 62.613 & 1.224 & 5.322 & 62.613 & 1.556 & 6.766 & 59.981 \\
\hline 7 & 1.116 & 4.850 & 67.463 & 1.116 & 4.850 & 67.463 & 1.434 & 6.236 & 66.216 \\
\hline 8 & 1.083 & 4.710 & 72.173 & 1.083 & 4.710 & 72.173 & 1.370 & 5.956 & 72.173 \\
\hline 9 & .899 & 3.908 & 76.081 & & & & & & \\
\hline 10 & .813 & 3.534 & 79.615 & & & & & & \\
\hline 11 & .757 & 3.290 & 82.905 & & & & & & \\
\hline 12 & .564 & 2.451 & 85.356 & & & & & & \\
\hline 13 & .553 & 2.406 & 87.762 & & & & & & \\
\hline 14 & .474 & 2.063 & 89.825 & & & & & & \\
\hline 15 & .409 & 1.780 & 91.604 & & & & & & \\
\hline 16 & .370 & 1.607 & 93.211 & & & & & & \\
\hline 17 & .337 & 1.467 & 94.678 & & & & & & \\
\hline 18 & .304 & 1.322 & 96.000 & & & & & & \\
\hline 19 & .223 & .970 & 96.969 & & & & & & \\
\hline 20 & .207 & .901 & 97.870 & & & & & & \\
\hline 21 & .182 & .791 & 98.661 & & & & & & \\
\hline 22 & .164 & .713 & 99.374 & & & & & & \\
\hline 23 & .144 & .626 & 100.000 & & & & & & \\
\hline
\end{tabular}


Based on the results of our survey, we have derived six factors including penetrating strategy, infrastructures, competitive pricing, targeting appropriate market, communication strategy and crystal clear characteristics.

\section{The results}

In this section, we present details of our findings on six influencing factors.

\subsection{The first factor: Penetrating strategy}

The first factor is associated with penetrating strategy. Table 3 demonstrates details of our survey. As we can observe from the results of Table 3, "Social values" is the most important factor, followed by improvement on consumer's perception, consumer's expectation from a product and consumer preferences.

\section{Table 3}

The summary of factors associated with penetrating strategy

\begin{tabular}{lllll}
\hline Option & Factor weight & Eigenvalues & \% of variance & Accumulated \\
\hline Improvement on consumer's perception & .798 & & & 48.657 \\
Social values & .803 & 2.433 & 48.657 & \\
Consumer's expectation from a product & .684 & & & \\
Interpersonal communication effects & .563 & & & \\
Consumer preferences & .605 & & & \\
\hline Cronbach alpha $=0.724$ & & &
\end{tabular}

\subsection{The second factor: Infrastructures}

Infrastructure is the second important factor and it includes four factors, which are summarized in Table 4 as follows,

Table 4

The summary of factors associated with infrastructure

\begin{tabular}{llccc}
\multicolumn{1}{c}{ Option } & Factor weight & eigenvalues & \% of variance & Accumulated \\
\hline Rules and regulations & .830 & 2.226 & 55.643 & 55.643 \\
Environment issues & .689 & & & \\
Government support & .692 & & \\
Nano technology & .724 & & \\
\hline Cronbach alpha $=0.732$ & & & & \\
\hline
\end{tabular}

According to the results of Table 4, "Rules and regulations" is number one priority followed by "Government support", "Environment issues" and "Nano technology".

\subsection{The third factor: Competitive pricing}

Competitive pricing is another important factor with three items summarized in Table 5.

Table 5

The summary of factors associated with competitive pricing

\begin{tabular}{llccc}
\hline \multicolumn{1}{c}{ Option } & Factor weight & eigenvalues & \% of variance & Accumulated \\
\hline Pricing strategy & .752 & & & \\
Product characteristics & .801 & & & \\
Replacement products & .881 & 1.984 & 66.122 & 66.122 \\
\hline Cronbach alpha $=0.738$ & & &
\end{tabular}


According to the results of Table 5, "replacement products" is the most important component in organizational assessment followed by "product characteristics" and "pricing strategy".

\subsection{The fourth factor: Targeting appropriate market}

Targeting appropriate market is another important factor with three items summarized in Table 6 . According to the results of Table 6, "Knowledge management" is the most important component in organizational assessment followed by "Customer oriented organization culture", "Having a unified instruction" and "Outsourcing mechanisms".

\section{Table 6}

The summary of factors associated with targeting appropriate market

\begin{tabular}{lcccc}
\hline \multicolumn{1}{c}{ Option } & Factor weight & eigenvalues & \% of variance & Accumulated \\
\hline Marketing strategy & .830 & 1.853 & 61.781 & 61.781 \\
Penetrating new markets & .785 & & & \\
Investigation on market change & .741 & & & \\
\hline Cronbach alpha $=0.55$ & & & &
\end{tabular}

\subsection{The fifth factor: Communication strategy}

Communication strategy is another important factor with three items summarized in Table 7. According to the results of Table 7, "Creating trust among customers" is the most important component in organizational development followed by "Customer trust to brand", and "Communication with customers".

\section{Table 7}

The summary of factors associated with organizational development

\begin{tabular}{lcccc}
\multicolumn{1}{c}{ Option } & Factor weight & eigenvalues & \% of variance & Accumulated \\
\hline Customer trust to brand & .802 & & & \\
Communication with customers & .756 & & & \\
Creating trust among customers & .813 & 1.877 & 62.551 & 62.551 \\
\hline
\end{tabular}

\subsection{The sixth factor: Crystal clear characteristics}

Crystal clear characteristics are the last important factors with two items summarized in Table 8. According to the results of Table 8, "Exclusive product characteristics" is the most important item followed by "Distinguished brand".

\section{Table 8}

The summary of factors associated with Intelligence data strategies

\begin{tabular}{lcccc}
\hline \multicolumn{1}{c}{ Option } & Factor weight & eigenvalues & \% of variance & Accumulated \\
\hline Distinguished brand & .796 & & & \\
Exclusive product characteristics & .796 & 1.269 & 63.427 & 63.427 \\
\hline Cronbach alpha $=0.421$ & & &
\end{tabular}

\section{Conclusion}

This paper has presented an investigation on the role of brand image on customer loyalty on rubber industry. The study was performed among some Iranian experts in rubber industry and the study has determined six factors including penetration strategy, infrastructure characteristics, competitive pricing, target marketing strategy, communication strategy and market characteristics. In terms of 
penetrating strategy, "Social values" has detected as the most important factor, followed by improvement on consumer's perception, consumer's expectation from a product and consumer preferences. Infrastructure was the second factor in our study where "Rules and regulations" was number one priority followed by "Government support", "Environment issues" and "Nano technology". Competitive strategy was another important factor where "replacement products" was the most important component in organizational assessment followed by "product characteristics" and "pricing strategy". Targeting appropriate market was another important factor with three items where "Knowledge management" was the most important component in organizational assessment followed by "Customer oriented organization culture", "Having a unified instruction" and "Outsourcing mechanisms". Communication strategy is another important factor with three items where "Creating trust among customers" was the most important component in organizational development followed by "Customer trust to brand", and "Communication with customers". Finally, Crystal clear characteristics are the last important factors with two items where "Exclusive product characteristics" is the most important item followed by "Distinguished brand".

\section{Acknowledgment}

The authors would like to thank the anonymous referees for their construction comments on earlier version of this work.

\section{References}

Aaker, J.L. (2010). Dimensions of brand image. Journal of Marketing Research, 34(3), 347-57.

Berry, L. L. (2000). Cultivating service brand equity. Journal of the Academy of Marketing Science, 28(1), 128-137.

Erdem, T., \& Swait, J. (1998). Brand equity as a signaling phenomenon. Journal of consumer Psychology, 7(2), 131-157.

Erdem, T., Swait, J., \& Louviere, J. (2002). The impact of brand credibility on consumer price sensitivity. International Journal of Research in Marketing,19(1), 1-19.

Erdem, T., \& Swait, J. (2004). Brand credibility, brand consideration, and choice. Journal of Consumer Research, 31(1), 191-198.

Franco, J. J. (1990). Customer satisfaction: The partnership imperative. Training and Development Journal, 44(7), 80-82.

Gilliland, D. I., \& Bello, D. C. (2002). Two sides to attitudinal commitment: the effect of calculative and loyalty commitment on enforcement mechanisms in distribution channels. Journal of the Academy of Marketing Science, 30(1), 24-43.

Harris, L. C., \& Goode, M. M. (2004). The four levels of loyalty and the pivotal role of trust: a study of online service dynamics. Journal of retailing, 80(2), 139-158.

Hsieh, A.T., \& Li, C.K. (2011). The moderating effect of brand image on public relations perception and customer loyalty. Marketing Intelligence \& Planning, 26(1), 26-42.

Leuthesser, L., Kohli, C.S. \& Harich, K.R. (2010). Brand image: the halo effect measure. European Journal of Marketing, 29(4), 57-66.

Stigler, G. J. (1961). The economics of information. The journal of political economy, 69(3), 213 225.

Stiglitz, J. E., \& Weiss, A. (1981). Credit rationing in markets with imperfect information. The American economic review, 71(3), 393-410.

Sweeney, J., \& Swait, J. (2008). The effects of brand credibility on customer loyalty. Journal of Retailing and Consumer Services, 15(3), 179-193.

Wray, B., Palmer, A., \& Bejou, D. (1994). Using neural network analysis to evaluate buyer-seller relationships. European Journal of Marketing, 28(10), 32-48. 